\title{
Difficulties and Errors of Differential Diagnostics Androgen-Secreting Tumors of the Addrum and Ovary on The Example of Clinical Case. Results of Treatment
}

\author{
Tereshchenko IV* and Marchukova EA \\ Perm State Medical Academy, Russia
}

*Corresponding author:Tereschenko Irina Vladimirovna, Department of Endocrinology and Clinical Pharmacology, Perm State Medical Academy, Russian Agency for Health Care, Russia.

Received Date: January 07, 2019

Published Date: January 16, 2019

\begin{abstract}
The goal is to analyze the possibilities of differential diagnostics of androsteroma and virializing ovarian tumors and to analyze the case of erroneous adrenalectomy. A patient of 57 years with ovarian virilization was removed the adrenal gland. Hypotestosteronemia persisted. It was proposed to remove the second adrenal gland, the patient refused only after 5 years.
\end{abstract}

Keywords: Androsteroma; Arrhenoblastoma; Tekoma; Adrenalectomy; Virile syndrome

\section{Introduction}

Androsteroma, a hormonally active virializing tumor from the reticular layer of the adrenal cortex, is extremely rare. Variolating ovarian tumors -sertolistromalnokletochnye and steroid - cell are also a rare pathology, although they are more common with androsteroma. Androsteroma and virializing ovarian tumors do not differ in the clinical picture. Therefore, the differential diagnosis of these tumors is difficult. However, the determination of the level of androgens and their fractions in the blood, which has become routine in recent years, makes it possible to suspect a source of virilization. Tumor cell secretion androgens and their fractions depends on the origin of the tumor, which is very important to consider when differential diagnosis. Visualization androgensekretiruyusch her tumor and performed echo graphically (US), by computer or magnetic resonance imaging (CT, MRI) of the adrenal glands and organs of a small pelvis and helps in the selection of surgical intervention. The available literature mainly contains a description of individual cases of virializing GTC Hawley, and in publications is not met examples of differential diagnostic errors [1-5].

\section{Purpose of Work}

Analyze the possibilities of differential diagnosis of androsteroma and virializing ovarian tumors and analyze the case of erroneously adrenalectomy.

\section{Clinical Observation}

Patient G- va, 57 years old, appealed for consultation in May 2017 years complaining of alopecia, beard and mustache growth (she shaves daily), hair growth on her back, along the back of her thighs, around the anus, coarseness of her voice.

\section{Anamnesis of life}

Signs of virilization appeared in 2011 at the age of 54 years, which was regarded by doctors as menopausal alopecia. In the fall of 2013, a hormonal examination was conducted. The level of testosterone in the blood was $261 \mathrm{ng} / \mathrm{dl}$ (the norm of $5-103 \mathrm{ng} / \mathrm{dl}$ ), free testosterone $54 \mathrm{pg} / \mathrm{l}$ (the norm of $0-4.1 \mathrm{pg} / \mathrm{l}$ ) Repeatedly repeated control testosterone levels. During the year, giptestosteronemia was persistent: 241-424ng/dl. In November 2014 she was hospitalized in the endocrine logical department for examination.

\section{Installations}

Testosterone contentin the blood $424 \mathrm{ng} / \mathrm{dl}, 170 \mathrm{H}$ - progesterone and 11.08nmol/L (normal $<2.1 \mathrm{nmol} / \mathrm{L}$ ), androstenedione and $1.5 \mathrm{ng} / \mathrm{ml}$ (normal 0.4-4.1ng/ml), dihydrotestosterone a $334 \mathrm{pg} / \mathrm{ml}$ (normal 24- $450 \mathrm{pg} / \mathrm{ml}$, estradiol and $45.72 \mathrm{pg} / \mathrm{ml}$ (normal $0-41 \mathrm{pg} / \mathrm{ml}$ ), cortisol and $9.2 \mathrm{mg} / \mathrm{dl}$ (normal $5-25 \mu \mathrm{g}$ / 
dl ), DHEA $27.4 \mu \mathrm{g} / \mathrm{dl}$ (the norm 35-430 $\mu \mathrm{g} / \mathrm{dl}$,), aldosterone and $21.6 \mathrm{ng} / \mathrm{dl}$ (the norm 2.56-44.5ng/dl ), renin a $18.6 \mathrm{mIU} / \mathrm{l}$ (normal $4.4-46.9 \mathrm{mIU} / \mathrm{l}$ ), TSH $2.27 \mathrm{mIU} / \mathrm{ml}$ (norm $0.4-2.0 \mathrm{mIU} /$ $\mathrm{ml})$. Ultrasound of the pelvic organs was performed: intramural uterine fibroids were detected $(15 \mathrm{~mm}$ in diameter); the right ovary is usually located, dimensions $32 \times 23 \times 17 \mathrm{~mm}$; heterogeneous echo structure, medium echogenicity, without antral follicles. The left ovary is located along the left edge of the uterus, dimensions 15x7 mm, homogeneous echo structure, usual echogenicity, without antral follicles. Conclusion: ECHO-signs of uterine fibroids. Increasing the size of the right ovary.

Based on the conducted survey, an androsteroma apodised. In order to visualize the tumor twice at an interval of six months was performed multislice computed tomography (CTM) adrenal glands located generally on both sides somewhat enlarged, a wavy convex contour, homogeneous structure. On the right between the legs there is a rounded education up to $14 \mathrm{~mm}$ in diameter with clear contours, fat density (-87-92 Hu), the contrast does not save. Para adrenal fiber is not changed. Conclusion: adrenal hyperplasia. Education in the right adrenal gland (lipoma).

Six months later, CT scan of the adrenal glands did not reveal the dynamics. The patient underwent a glucose tolerance test: fasting glucose $5.6 \mathrm{mmol} / \mathrm{l}, 2$ hours after ingestion of $75 \mathrm{~g}$ glucose$9.6 \mathrm{mmol} / \mathrm{l}$. Androsteroma of the right adrenal gland. Type 2 diabetes mellitus first identified. The patient was transferred to the surgical department, laparoscopic right-sided adrenalectomy was performed. The following description of the macro preparation is presented: a piece of tissue $4 \times 2 \times 1.6 \mathrm{~cm}$ in size, $1 \mathrm{~mm}$ cortical substance in the section, $2 \mathrm{~mm}$ brain tissue; extensive hemorrhage; Histological the remote tissue structure: in adrenal tissue has a cluster of bright and dark rounded cells containing lipids in the cytoplasm.

One month after the operation, the blood testosterone level was $225 \mathrm{ng} / \mathrm{dl}$, cortisol $13.7 \mu \mathrm{g} / \mathrm{dl}$. Subsequently, virilization progressed, hypotestosteronemia remained within 241-245ng/dl. Repeated ultrasound of the pelvic organs - without negative dynamics; there is an increase in the right ovary. MKT of abdominal organs: voluminous formations in the abdominal cavity were not detected. Hyperplasia of the left adrenal gland. The patient was offered adrenalectomy left adrenal gland, which she refused, and before May 2017 not to doctors addressed.

In April 2017, on her own initiative, checked the level of testosterone in the blood, which amounted to $305 \mathrm{ng} / \mathrm{dl}$, which was the reason for applying for a consultation. Since the adrenal cause of hyperandrogenism was immediately rejected, the patient is directed to the pelvic organs MKT: the uterus is an evolutive change. The left ovary is not clearly visualized. In the structure of the right ovary, the formation of up to $16-18 \mathrm{~mm}$ is determined, which intensively accumulates contrast, with a peak in the density increase in the venous phase, with subsequent partial leaching into the delayed phase.

\section{Conclusion}

Hyper vascular formation of the right ovary.

\section{Objective status}

Masculine phenotype. Reduced body fat around the pelvic girdle. Motility, men's gait. The voice is low with male overtones (bar phony). Male type alopecia. Pronounced hirsutism and hypertrichosis. The thyroid gland is not enlarged. The mammary glands are hypo trophic, sluggish, and abundant hair growth around the areolas. From the internal organs of the pathology was not detected BP 135/80.

\section{Gynecological status}

Clitoromegaly, the mucous membranes of the perineum are atrophic, cyanotic. Labia ipoplazi Mr. Rowan. The uterus is small in size. The ovaries are not palpable.

Thus, the patient is symptomatic and virilization def e minizatsii.

\section{Clinical diagnosis}

Virializing tumor of the right ovary. Hypertension stage II, risk 2.

\section{Treatment}

The patient is asked to surgical treatment, which she accepted at once, and more checked twice testosterone la (258ng/dl, 232ng/ dl). Produced laparoscopic bilateral adnexectomy 15.12.2017 year. It turned out I'm an ovary on the left, involutive, $1.5 \times 1.5 \times 0.7 \mathrm{~cm}$, tightly elastic, gray on the cut, with small single burgundy patches. The right ovary $2-3-2 \mathrm{~cm}$, on its lateral surface is located glandular -cystic structure of burgundy color, without capsule, diameter - 1.5 to $2 \mathrm{~cm}$, the cut motley (gray-yellow-twitch the centers of the red and brown) irregular shape. Histologists I: tumor from large polygonal $\mathrm{x}$ cells similar to granulozo -lyuteinovymi cells, resembling a corpus luteum cells as diffuse tyazh, fields, nests, with sites of cystic degeneration; the vasculature in the tumor is well developed. Conclusion: steroid- lipid cells unclassifiable tumor of the right ovary; focal (nodular) hypertecosis of the left ovary (hematoxylineosin staining; histochemical study was not conducted).

\section{Results}

After surgery in the blood levels of testosterone became $<20 \mathrm{ng}$ / ml, color appeared sparse hair, disappeared barifoniya. However, frequent hot flushes began to bother. The level of FSH corresponded to the norm of the menopausal period $(33.7 \mathrm{mIU} / \mathrm{ml}$; the norm was up to $133.4 \mathrm{mIU} / \mathrm{ml}$ ), the content of estradiol in the blood was $<10 \mathrm{pg} / \mathrm{ml}$. After 3 months she began to feel good, the tides stopped spontaneously. Glycemia is monitored and monitored: normal carbohydrate metabolism. Last viewed in XII -2 018g. No complaints. Alopecia disappeared. Hirsutism is less pronounced. Does not need daily shaving (visits the beautician once a month). Gait, motility, voice, phenotype as a whole - feminine. The rapid and significant regression of virilization is amazing.

Clinical manifestations androsteroma and virializing ovarian tumors are similar, which creates difficulties in diagnosis. Symptomatology and depend on the degree of testosterone tumor cells hypersecretion. However, androsteroma occurs more often at the age of 40 years [1,2], virilizing ovarian tumors can develop at any age, but mainly in menopause [3-5]. Hormonal shifts with 
adrenal and ovarian tumor hyperandrogenism have cardinal differences (Table 1).

Table 1: Hormonal changes in virilizing tumors adrenal and Ovarian virilizing tumor.

\begin{tabular}{|c|c|c|}
\hline Hormone & Androsteroma & $\begin{array}{c}\text { Ovarian Virilizing } \\
\text { Tumor }\end{array}$ \\
\hline Testosterone & $\begin{array}{l}\text { Persistent and high } \\
\text { excess* }\end{array}$ & $\begin{array}{c}\text { Persistent and high } \\
\text { excess* }\end{array}$ \\
\hline Free testosterone & Moderate increase & $\begin{array}{c}\text { Persistent and high } \\
\text { excess* }\end{array}$ \\
\hline DHEA & $\begin{array}{l}\text { Significant and persistent } \\
\text { increase (increases } 10 \\
\text { times and }>\text { ) }\end{array}$ & $\underset{\substack{\text { Normal, possibly }<\\
\text { normal* }}}{ }$ \\
\hline $17 \alpha \mathrm{OH}$ progesterone & $\begin{array}{l}\text { Significant and persistent } \\
\text { increase }\end{array}$ & $\begin{array}{c}\text { Normal or slightly } \\
\text { elevated* }\end{array}$ \\
\hline Androstenedion & $\begin{array}{l}\text { Significant and persistent } \\
\text { increase }\end{array}$ & Fine* \\
\hline Dihydrotestosterone & Normal or elevated & Normal or elevated \\
\hline Estradiol & Always down & $\begin{array}{l}\text { Normal, can be } \\
\text { upgraded* }\end{array}$ \\
\hline
\end{tabular}

*changes in the level of hormones in the blood of the observed patient.

Clearly, virilization and determinism in the observed patient created ovarian hypotestosteronemia. Her hormonal changes directly pointed to the ovarian and not adrenal genesis of hypotestosteronemia, since the blood content of adrenal fractions of androgens was not increased, and DHEA (the main indicator of adrenal hyperandrogenic!) Waseven reduced. In case of virilizing ovarian tumors, mixed hypersecretion of testosterone and estrogen (estradiol and estrone) can be observed. Obviously, this option was in the presented patient, since her estradiol level was slightly elevated.

To visualize androgensekretiruyusch tumors should be carried out and ultrasound, and CT (MRI) of the adrenal glands and pelvic organs. It should be noted that, in the observed patient, no pelvic CT scan was performed before adrenalectomy, although the right ovary was echo graphically enlarged, and the tumor was not viewed. The results of a double adrenal ICD MCC clearly indicated that it does not have an androsteroma, since an androsteroma always has a dense connective tissue capsule, is located in the tissue of the adrenal gland itself, and not between its legs, actively accumulates contrast (ultraravist).

It is known that with hypertension and long-term use of antihypertensive drugs, secondary hyper aldosteronism and adrenal hyperplasia may develop. This explains bilateral hyperplasia of both adrenal glands in the observed patient. (hypertension in her> 15 years). There was no doubt during the MCC that the rounded tumor between the legs of the adrenal gland is a lipoma. The morphological description of the lipoma in the patient is not done. Depending on the lipoma cell composition may be lipofibroma (soft lipoma, represented mainly by adipose tissue), fibro lipoma (dense touch lipoma, consisting of fat and connective fibrous tissue with prevalence of the latter), angiolipoma with plenty of blood vessels, miolipoma-zhirovik, containing muscle fibers, myelolipoma is a rare species ( adipose tissue is mixed with hematopoietic, it can be found in the tissue of the retroperitoneal space and pelvis, as well as in the adrenal glands). The patient may have removed the myelolipoma, as a massive hemorrhage was found in the macro preparation [6]. Lipoma of the adrenal gland in a patient can be fairly attributed to hormonally inactive incidentalome (not accidentally, when the adrenal ICT was performed, the formation did not accumulate contrast), and since the diameter of the lipoma did not exceed $1.5 \mathrm{~cm}$, there was no indication for adrenalectomy. Changes in the adrenal glands, the patient - their hyperplasia, presence of lipoma - created additional difficulties in the differential diagnostics. However, for the healing operation - adrenalectomy the patient was made unreasonably and in vain.

Virilating ovarian tumors can form from its various elements. While in the world there is no single classification of masculinizing ovarian tumors. Allocategranulozokletochnuyu tumor tekomu, androblastomu (tumor cells of sex cord - or Sertoli cells Le ydiga cells) lipidokletochnye tumors (lyuteomy). Often, a morphological diagnosis can only be made by means of histochemistry, which was not done by the patient. Therefore, an exact morphological diagnosis has not been made. However, yrazhennost virilization and speed of its progression independent of ghee with ontological structure of ovarian tumors, but only on its androgensekretornoy activity. Topic diagnosis of ovarian tumors always presents great difficulties, since they are small in size and can be localized in the area of the ovary collar (this makes visualization difficult during ultrasound). They may not be clearly determined by ultrasound of the ovaries, as was the case with the observed patient. In such cases, the unilateral enlargement of the ovary should be alarming. Heredoc they lack capsule; they are bilateral or recur after surgery; there is always the risk of their malignancy, which means that surgical treatment should be carried out as early as possible. In a patient, the approximate duration of the disease before the removal of the tumor was 7 years! Hypertecosis of the left ovary aggravated virilization, and in addition, it was a precancerous condition. Bilateral adnexectomy was necessary. Uterus extirpation was not required (the principle of reducing surgical aggression was observed).

Known gipertekoz characterized by insulin resistance. In yrazhennost stromal hypertecosis is directly related to how significant insulin resistance is: The $\beta$-cells have insulin receptors, and insulin helps them to produce androgens. Reducing the sensitivity of cells to insulin causes nak about Nia glucose pleas in the blood that is not able to penetrate the cells, which manifested itself in the patient. It is important to note that after surgery, her carbohydrate metabolism returned to normal, i.e. a violation of the glucose tolerance test was obviously a manifestation of hypertecosis, and the diagnosis of type 2 diabetes mellitus was wrongly set.

\section{Findings}

1. Despite the complete clinical similarity of androsteroma and virilizing ovarian tumors, the resulting hormonal changes differ dramatically, and this helps differentiate the localization of the tumor.

2. In order to avoid diagnostic errors for topical diagnosis of a virilizing tumor, it is always necessary to perform ultrasound and CT or MRI of the adrenal glands and pelvic organs. 
3. With androgen- secreting tumors of both the adrenal gland and the ovary, early surgical treatment is required, which will eliminate defemination, reduce virilization, and prevent malignancy of tumor tissue.

\section{Acknowledgement}

None.

\section{Conflict of Interest}

No conflict of interest.

\section{References}

1. Danilowicz K, Albiger N, Vanegas M, Gómez RM, Cross G, et al. (2002) Androgen- secreting adrenal adenomas. Obstet Gynecol 100 (5 Pt 2): 1099-1102.
2. Mylarappa P, Pathade A, Javali T, Ramesh D (2014) Virilizing lipoadenoma of the adrenal gland in a pre-pubertal girl: A rare case. Indian J Urol 30(2): 219-221.

3. Aminimoghaddam S, Ebrahimi AS, Hashemi F (2012) A rare ovarian tumor, leydig stromal cell tumor, presenting with virilization: a case report. Med J Islam Repub Iran 26(4): 185-188.

4. Horta M, Cunha TM (2015) Sex cord-stromal tumors of the ovary: a comprehensive review and update for radiologists. Diagn Interv Radiol 21(4): 277-286.

5. Chen M, Zhou W, Zhang Z, Zou Y, Li C (2018) An ovarian Leydig cell tumor of ultrasound negative in a postmenopausal woman with hirsutism and hyperandrogenism. A case report. Medicine (Baltimore) 97(10): e0093.

6. Damjanov I, Katz SM, Catalano E, Mason D, Schwartz AB (1979) Myelolipoma in a heterotopic adrenal gland: light and electron microscopic findings. Cancer 44(4): 1350-1356. 